\title{
Brief Glimpses of Beauty. Thinking about the History of Lithuanian Photography
}

\section{Adam Mazur}

University of Arts in Poznań

Al. Marcinkowskiego 29, 60-967 Poznań, Poland

adam.mazur@uap.edu.pl

- The article proposes a critical re-thinking of the multi-layered phenomenon of Lithuanian photography. From the beginning, in the 19th century Lithuanian photography cherished an exceptional status within a cultural landscape, being considered a vehicle of lofty, patriotic emotions. The article is reassessing the social and cultural role of Lithuanian photographers and is looking into a symptomatic lack of synchronicity with the medium's grand narratives. The Lithuanian history of photography seems to be a consistent and exceptional narrative developed within a relatively small milieu of artists based in their homeland as well as Lithuanian émigrés. According to the author, indexical and documentary qualities of photography constitute the core of the phenomenon. The text is advocating inclusivity for non-Lithuanian authors, be it Polish Lithuanians, Russians, Jews, Germans, or Lithuanian Americans. Looking at photographs from the perspectives of literature (quoting Marcelijus Martinaitis and Tomas Venclova) and contemporary art (Jonas Mekas and Fluxus) may be also useful in reshaping and opening up the discourse of the discipline.

Keywords: Lithuanian Photography, Lithuanian Art, Lithuanian History, documentary photography, art photography, Balys Buračas, Jan Bułhak, Antanas Sutkus, Jonas Mekas. 
Lithuania is a land of photographers, says Balys Buračas. ${ }^{1}$ This claim of the Lithuanian artist is surprising, given that Lithuania does not have a history of a photo industry, or factories of photosensitive materials, cameras, lenses, and matrices. Neither does it have any inventors or pioneers of photography of textbook fame. Reportage, commercial, advertising, science, or sports photography have never quite evolved to the European, much less global, level. The reluctance of the locals to leave the country results in a lack of photographic expeditions and colonial conquests with a camera in hand. Without big metropolises, there is no street photography, and no distinct movements of avant-garde and neo avant-garde photography. Without a grand history, there are no world-renowned iconic pictures. Nonetheless, Buračas is right: Lithuania is a country of photography and photographers.

In the summer of 1839 , when Daguerre announced his discovery of the medium of photography, Lithuania did not exist on the map of Europe and the older generation still held the Grand Duchy of Lithuania in its memory. The Russian-occupied Lithuania, reduced to the role of a Baltic province, saw the evolution of photography take a surprising course. Progress was largely theoretical and novelties imported from the distant West were being adopted slowly. The great, old Lithuanian aristocracy, with count Benedykt Tyszkiewicz and count Kazimierz Stanisław Kossakowski at the forefront, approached photography as a hobby and a form of entertainment. The lesser nobility and some members of the bourgeoisie saw photography as a path of social advancement and an opportunity for artistic expression. At the turn of the twentieth century, Lithuanians began to see photography, which was brushed off elsewhere as a petite bourgeois and banal activity, as a noteworthy phenomenon. It is therefore no wonder that both the "Young Lithuanians", associated with the Lithuanian national revival, as well as the Lithuanian Poles considered photography to be an art expressing the loftiest patriotic emotions. Whether pictorial or documentary, there is something about Lithuanian photography - a certain essence of artistry. The lack of synchronicity with the global centres led to a delayed and extended interest in pictorialism, while the avant-garde remained an 
abstract, distant, and bizarre idea. Nonetheless, Lithuanian photographers held an exceptional status. Even after the Second World War, during the dark times of the Soviet occupation, in spite of the communist uravnílov$k a$, members of the so-called Lithuanian school of photography belonged to the elite, combining an aristocratic attitude with an artistic spirit. Lithuanian photography is vigilant, profound, and immersed in reality and common history. It is a process of documenting the passing world and a tool of lyrical expression. Whether it is the banality of the everyday, scenes of violence, sickness, disability, or death, a Lithuanian photographer is able to find beauty in the subject and record it. The more the world disintegrates, the more stubbornly Lithuanians insist on searching for instances of beauty.

\section{Unknown Lithuanian photography}

Lithuanian photography is among the best chronicled ones, not just within the region. Studies of Latvian and Estonian photography are still in the early stages in comparison to the Lithuanian photography discourse. The comparison of Lithuania to Ukraine or Belarus looks similar. Polish researchers also look with envy to the excellent series of editions describing Polish photographers in Lithuania, such as Jan Bułhak, Józef Czechowicz, Abdon Korzon, and Stanisław Kossakowski. ${ }^{2}$ Perhaps the level of research in Lithuania can be best compared to such countries as the Czech Republic or Hungary. In those countries, photography is also treated not only as a major field of art, an important element of the heritage, but also as nothing short of a national treasure, crucial to the contemporary cultural identity. Paradoxically, compared to Hungary and the Czech Republic, there is a striking deficit when it comes to the presence of Lithuanian photography abroad. None of the comprehensive studies of the history of world photography feature Lithuanian authors or photographs from Lithuania. This problem does not just concern the popular papers which replicate an established canon, but also specialist publications, which - like the book edited by Michel Frizot - dedicate a lot of space to Central and Eastern

2 Jan Buthak. Vilnius, vols. 1-3, sud. Jūratė Gudaitė, Vilnius: Lietuvos nacionalinis muziejus, 2011, 2012, 2013; Juozapas Čechavičius 1818-1888. Fotografijos / Photographs, sud. Jūratė Gudaitè, Vilnius: Lietuvos nacionalinis muziejus, 2016; Dainius Junevičius, Abdonas Korzonas pirmasis Vilniaus vaizdu fotografas, Vilnius: Vilniaus dailès akademijos leidykla, 2018; Jolita Mulevičiūtè, „Vaitkuškis“. Grafas Stanislovas Kazimieras Kosakovskis (1837-1905) ir XIX amžiaus mégèju fotografija, Vilnius: Lietuvos kultūros tyrimų institutas, 2015. 
European photography. ${ }^{3}$ What is worse, Lithuania and Lithuanians are missing even from the more specialised papers concentrating on the region, such as Matthew S. Witkovsky's catalogue. ${ }^{4}$ This astonishing absence can no longer be explained by the over half-a-century-long Soviet occupation. Moreover, in the last three decades there has been no shortage of international accomplishments of individual artists, shows, presentations, and publications. ${ }^{5}$ One would imagine that the names of Antanas Sutkus, Vitas Luckus, Rimaldas Vikšraitis, Algirdas Šeškus, and Indrè Šerpytytė would have entered the world canon by now. And yet, their names are missing from publications on contemporary photography. Why, despite all these efforts by the photography circles and texts by prominent historians, are we dealing with a situation similar to the narrative of an "unknown Latvian photography", ${ }^{6}$ as diagnosed by Ivars Gravlejs? This fundamental question leads to further ones: can we even imagine another history of Lithuanian photography? What distinguishes Lithuanian photography and makes it original, beautiful, and constantly necessitating translation, if not discovery?

\section{Ici, là-bas}

In their article on the history of Lithuanian photography, three researchers - Vytautas Michelkevičius, Lina Michelkevičè, and Agnė Narušytė - make a convincing use of diagrams and drawings that allow us to better understand the intricacies of its discourse and the relationships within the photographic circles. ${ }^{7}$ The issue of Lithuanian photography may indeed be effectively illustrated in the form of a diagram based on the square proposed by the notable semiotician Algirdas Julien Greimas. By referring to the famous conceptualisation of the pair of notions "here" and "there", we may examine what is actually regarded as Lithuanian photography. "Here" means within Lithuania's contemporary political boundaries, where the

3 A New History of Photography, ed. Michel Frizot, Köln: Könemann, 1998.

4 Matthew S. Witkovsky, Foto: Modernity in Central Europe, 1918-1945, Washington: National Gallery of Art, 2007.

5 See awards and mentions for books and artists. To mention just those recognized at the Rencontres d'Arles festival: Vytautas V. Stanionis, Nuotraukos dokumentams / Photographs for Documents, ed. Gintaras Česonis, Kaunas: Kaunas Photography Gallery, 2013; Vitas Luckus, Works, eds. Margarita Matulytė, Tatjana Luckienè-Aldag, Vilnius: Lietuvos dailės muziejus, 2014; Rimaldas Vikšraitis, Martin Parr, The Real World, Kaunas: Kaunas Photography Gallery, 2010.

6 Ivars Gravlejs, Nežinoma Latvijos fotografija, Kaunas: Kaunas Photography Gallery, 2018.

7 Mapping Lithuanian Photography. Histories and Archives, eds. Vytautas Michelkevičius, Lina Michelkevičè, Agnė Narušytė, Vilnius: Mene, 2007. 
vast majority of the population - and photographers - are native Lithuanians. "There" means elsewhere, abroad, in the neighbouring Poland and Russia - the countries, differences with which form the foundation of Lithuania's modern identity, but "there" also means farther away, in the mythical "West", in the United States and Canada. When it comes to photographers based "here", the question arises regarding the authors who were active before the Second World War. Most of them were Poles or Jews. What do we do with them? Historiography tends to deal with facts such as Vilnius's location outside Lithuania's pre-war borders by absorbing and to some extent Lithuanising Polish and Jewish authors. One good example of such ground-breaking, inclusive discourse is the monumental publication Camera Obscura by Agnė Narušytė and Margarita Matulytė. ${ }^{8}$ This project could be described as "old Lithuanian" in spirit, as it refers to the identity of the multicultural and expansive Grand Duchy of Lithuania. ${ }^{9}$ It is not a coincidence that the photograph introducing the history of Lithuanian photography in Camera Obscura is a daguerreotype of Adam Mickiewicz. ${ }^{10}$ The portrait, taken in Paris, where Mickiewicz was exiled, shows the Romanticist artist born in Navahrudak (modern-day Belarus) whose output was of fundamental significance for the Lithuanian and Polish culture. "Here" becomes blurry, losing the precision of boundaries, whether political, cultural, or linguistic ones; it shifts towards "there", towards the Polish-speaking, Paris-based Great Emigration which longs for Lithuania. It is an important photograph, as the twentieth century also saw generations of Lithuanians forced into political emigration, whether banished and imprisoned in Siberia or having to escape to America, and in contemporary times, to the United Kingdom, for economic reasons. The diaspora is usually incorporated into the Lithuanian historical narrative, and the most popular contemporary Lithuanian artists include Jonas Mekas (associated with the New York scene) and the London-based Indrè Šerpytytè.

8 Agnè Narušytė, Margarita Matulytè, Camera Obscura. Lietuvos fotografijos istorija 1839-1945, Vilnius: Vilniaus dailès akademijos leidykla, 2016. Cf. chapters devoted to Lithuanian photography, by the same authors, included in The History of European Photography 1900-1938, vol. 1, ed. Vaclav Macek, Bratislava: Central European House of Photography, 2010, pp. 405-417; The History of European Photography 1939-1969, vol. 2, ed. Vaclav Macek, Bratislava: Central European House of Photography, 2014, pp. 447-467; The History of European Photography 1970-2000, vol. 3, ed. Vaclav Macek, Bratislava: Central European House of Photography, 2016, pp. 451-465.

9 Alfredas Bumblauskas, Wielkie Księstwo Litewskie. Wspólna historia, podzielona pamięć, trans. Alicja Malewska, Warszawa: Bellona, 2013.

10 Agnė Narušytè, Margarita Matulytè, op. cit, p. 36. 


\section{A part for the whole}

Without a doubt, Lithuania's absence from the nineteenth century political map, its fragmented history, and its fluid geopolitical situation throughout the twentieth century, as well as the constant tension between "here" and "there", have influenced Western historians of photography. Instead of exploring the nuances of the "here" and "there" geography or the frictions between the old and new Lithuanians, they prefer, for instance, like the aforementioned Witkovsky, to classify the interwar Vilnius circles as Polish photography, and to completely ignore those associated with Kaunas. ${ }^{11}$ In this context, one ought to reevaluate the legitimacy of the researchers' focus on the "Lithuanian" period in an author's body of work. One example is the aforementioned study of Jan Bułhak's art which concentrates on Vilnius and fails to frame the remainder of his output from a Lithuanian perspective. ${ }^{12}$ It seems that such fragmented Lithuanisation deprives the protagonist of depth and presents him as artistically single-faceted. The part attempts to dominate the whole - to no avail, however. Only by recognition - as has been the case with the recent Polish-Lithuanian (Kazimierz Stanisław Kossakowski, Stanisław Witkiewicz, Mikalojus Konstantinas Čiurlionis) or Israeli-Polish-Lithuanian (Moï Ver) research initiatives - of the Lithuanian element, and, moreover, by embedding it in a broader artistic context, can a fundamental change in the perception of the life and output of individual artists be generated. ${ }^{13}$ Such relationality and placing artists and photographs in a network of connections within the region and beyond does them justice and fits them into the "nothere" category from Greimas's diagram. This applies to all photographers operating within the borders of the once expansive and now long gone Grand Duchy, where there are no more Lithuanians, and even if there are any - like Andrew Miksys, who photographs Belarus - they are there in passing. ${ }^{14}$ Of course, "not-here" blends with "there", as is the case for all emigrants, who, even though they lived in Paris, London, New York, Warsaw, Toronto, and Tel Aviv, still thought of and missed Lithuania as they worked, even if against

11 Matthew S. Witkovsky, Foto.

12 Jan Buthak. Vilnius, vols. 1-3, sud. Jūratė Gudaitè.

13 Stanistaw Kazimierz Kossakowski. Kocham fotografię. For the Love of Photography. Myliu fotografija ed. Katarzyna Madoń-Mitzner, Warszawa: Dom Spotkań z Historią, 2019; The Ghetto Lane in Wilna. Hommage à Moi Ver, Vilnius: The Institute of Lithuanian Literature and Folklore, 2019; M.K. Čiurlonis. Litewska opowieść / Lithuanian Tale, Kraków: Międzynarodowe Centrum Kultury, 2015.

14 Andrew Miksys, Tulips, Vilnius: ARÖK Books, 2016. 
and despite Lithuania itself. This also applies to the well-known figures thus far excluded from the history of Lithuanian photography, such as Izis - Israëlis Bidermanas, a Lithuanian Jew working in Paris. Izis's absence from the narrative of Lithuanian photography could be compared to Hungarian historiography without Brassaï, or Polish one without Chim Seymour. Such stories would be artificially, if not chauvinistically, limited.

\section{History from the cloud}

The extension and inclusivity of the historiographic discourse, advocated in this essay, goes even beyond the borders of the Grand Duchy of Lithuania. "Not-here", in turn, may also be used in reference to all those photographers who are connected to Lithuania through photographs, which they take here, on site in Kaunas and Vilnius, or who reference Lithuania while being simultaneously associated with the discourse surrounding other photographic traditions: German, Russian, Polish, or American. One example may be the work of Roman Vishniac, who, shortly before the Second World War, in the course of photographing Polish Jews, arrived in Vilnius, where he created many of his iconic pictures showing Jews of... Lithuania. ${ }^{15}$ Vishniac is an emblematic figure, a Russian Jew who fled from the Bolsheviks to Berlin and from the Nazis to New York, photographing Polish Jews on his way. On the grim flip side of Vishniac's work are his candid photographs of Jewish executions, including in Paneriai near Vilnius, which are stored in German archives. In the minds of researchers, these world-renowned images become associated with Lithuania and they can no longer be ignored when constructing a persuasive and engaging narrative, which without them comes across as incomplete and unconvincing. When expanding the discourse, we point to connections which are subtle and often serendipitous, but nonetheless entrenched in images that are significant from the viewpoint of the history of world photography. According to a legend picked up by writers and poets, Lithuania comes from rain and its history is a "history from the cloud."16 And so is the country's photography - ephemeral and beautiful, fluid and merging with other stories in an ungraspable manner. It is not a history, but histories of photography. 


\section{Deschooling photography}

The inspiring heterogeneity of Lithuanian photography counters the Soviet-born founding myth of the so-called Lithuanian school of photography. ${ }^{17}$ Structurally resembling Jan Bułhak's interwar Vilnius Photo Club, it materialised in the form of the Society of Art Photography in 1969. The work of prominent enthusiasts of humanist documentary photography, including Antanas Sutkus, Romualdas Rakauskas, Aleksandras Macijauskas, Liudvikas Ruikas, Marius Baranauskas, Vitalijus Butyrinas, and Vitas Luckus, was impactful up until the new millennium, as Vytautas Michelkevičius demonstrates. ${ }^{18}$ Photography based on the faith in a documentary record, represented by Sutkus and his peers, saw moments of greatness in the 1970s and 80 s, depicting a subtly apologetic, humanist image of the socialist reality of the late USSR era [fig. 1]. The aesthetic of the Lithuanian school is based on a specific blend of influences from the exhibition The Family of Man curated by Edward Steichen and the Polish, Hungarian, and Czechoslovak humanist photo documentary. ${ }^{19}$ From the perspective of canonical studies, it is apparent that throughout its existence, the Lithuanian school did not cross paths with the history of world photography, which was already in a completely different place in the 1960s. As Margarita Matulyte points out, an attempt to re-imagine Lithuanian photography necessitates not only a critical reflection on the Soviet-era photography, but also a certain depreciation of the mythical school. ${ }^{20}$ The evaluation of that historical phenomenon has thus far predominantly accentuated studies of the relationship with the Soviet regime of Leonid Brezhnev, which tolerated and even favoured the group surrounding Antanas Sutkus. ${ }^{21}$ Meanwhile, the very vision of photography, brutal and tinged with masculine chauvinism, generated seductively beautiful pictures, which demand a critical reading. Undermining the monumentalism of Sutkus's school, researchers such as Agnè Narušyte and Margarita Matulyte point to the growth in the course of the school's existence and emphasise figures that remained on the sidelines as well as the alternative philosophy of

17 The term was first used by the Moscow critics Anri Vartanova and Konstantin Vishnevsky. See “Встреча с литовскими мастерами в Москве”, in: Советское фото, 9, 1969, p. 44.

18 Vytautas Michelkevičius, The Lithuanian SSR Society of Art Photography (1969-1989). An Image Production Network, Vilnius: Vilnius Academy of Arts Press, 2011.

19 History of European Photography, vol. 2, pp. 459-460.

20 Margarita Matulytè, Nihil obstat. Lietuvos fotografija sovietmečiu, Vilnius: Vilniaus dailès akademijos leidykla, 2011.

21 Vytautas Michelkevičius, op. cit., pp. 97-185; Margarita Matulytė, Nihil obstat, pp. 171-212. 


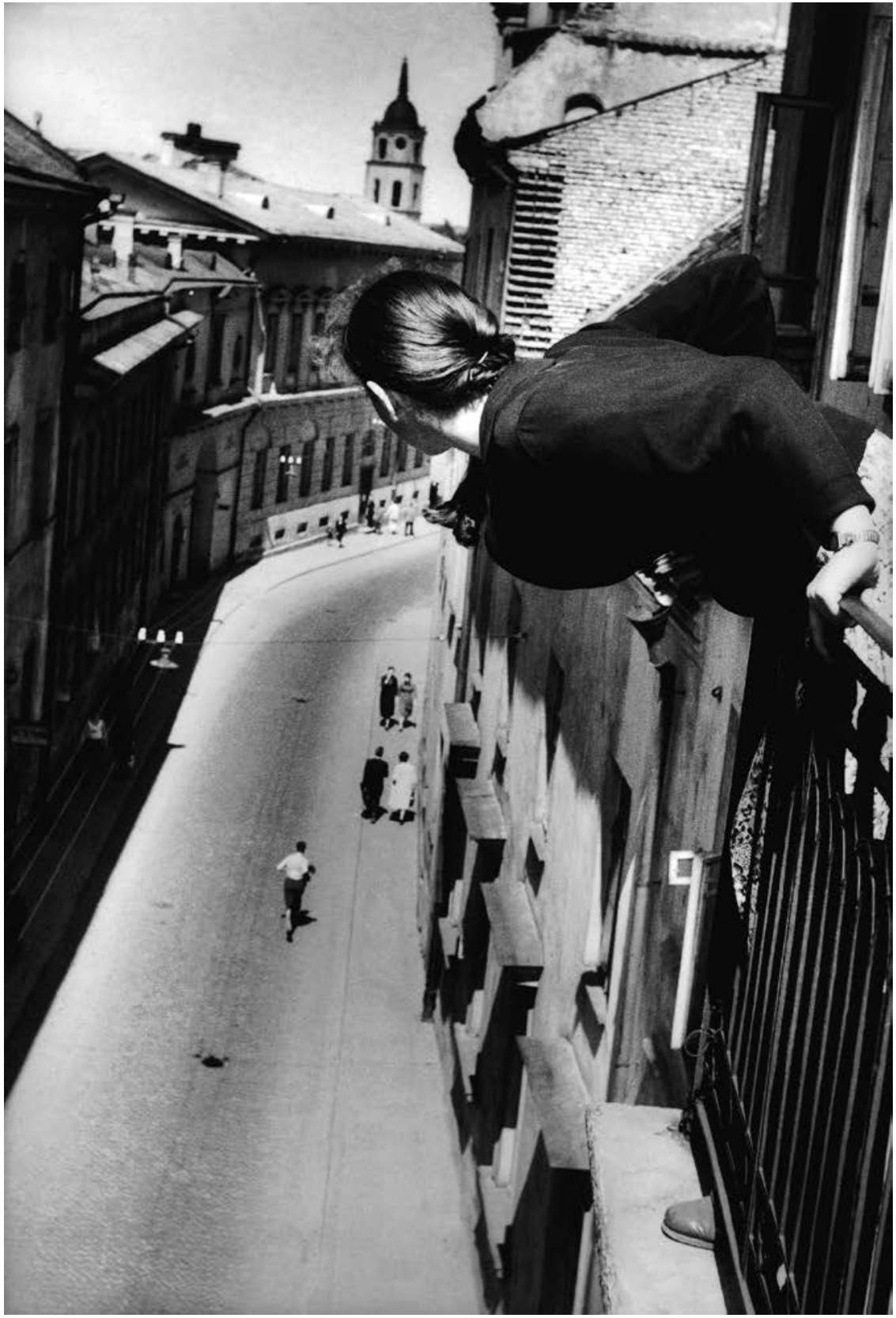

1.

Antanas Sutkus, Maratonas universiteto gatvejje, Vilnius, $1959,37 \times 55,3 \mathrm{~cm}$, atspaudas ant matinio popieriaus $50 \times 60 \mathrm{~cm}$, sidabro želatininis atspaudas, Antano Sutkaus nuosavybė, LATGA, Vilnius 2021
Antanas Sutkus, Marathon in Universiteto Street, Vilnius, 1959, silver gelatine print, LATGA, Vilnius 2021 
photography that they represented.22 The two historians counter the Lithuanian school with the stance of not only the so-called rebels from the 1980s, but also the representatives of the "new Lithuanian school" from the 1990s. ${ }^{23}$ The subsequent "grades" in the Lithuanian school are indeed more subtle, geared towards staged photography and free from the Brezhnevian style of pathos, but they still belong to the same school. Paradoxically, even while defying Sutkus, the photographers described in Boredom - like Remigijus Pačèsa, Vytautas Balčytis, or Alfonsas Budvytis - assert his dominant position. ${ }^{24}$ The same goes for representatives of the "new school": Alvydas Lukys, Gintautas Trimakas, and Saulius Paukštys. Perhaps one solution is to abandon the notion of subsequent schools and grades, with students following their masters, or otherwise, visibly bored, defiantly revolting against them. The deschooling could take the form of a definitive shift within the discipline's discourse and placing Fluxus, an equally Lithuanian phenomenon, at its centre.

\section{Liquid identity}

The nebulous group surrounding the Lithuanian emigrants George Maciunas and Jonas Mekas, comprising artists experimenting with the world and art, forms not a school, but a network of connections, guided predominantly by ideas in the contemporary spirit. Only after those ideas come the images, including photographs. Instead of a school, there is openness, liberty, as well as poetry and art. Such an approach to history does in fact pose a risk of diluting the "strong" brand of the Lithuanian school of photography. The question is whether that brand has actually benefited Lithuanian photography? Is the transition to contemporary art, in which photography is one of the fields of practice, not worth it? The change in perception of this phenomenon resembles the shift in perceiving the world and interpreting modernity demonstrated by Leonidas Donskis. ${ }^{25}$ The steadiness, normally associated with school knowledge, dissipates and is replaced with crisis, doubt, and critical reflection. Whatever one might think about such an approach to Lithuanian photography, it appears to be more suitable

22 History of European Photography, vol. 3, pp. 452-458.

23 Ibid., pp. 463-465.

24 Agnè Narušytė, The Aesthetics of Boredom. Lithuanian Photography 1980-1990, Vilnius: Vilniaus dailès akademijos leidykla, 2010.

25 Leonidas Donskis, Modernity in Crisis: A Dialogue on the Culture of Belonging, New York: Palgrave Macmillan, 2011. 
and align well with the cross-regional narrative. In the three-volume review of the world history of photography, written from the perspective of New York's Museum of Modern Art and edited by Quentin Bajac, Lithuania is represented by Fluxus's Jonas Mekas. ${ }^{26}$ In 2017, at documenta 14, Lithuanian photography was also represented by Jonas Mekas, accompanied by an anti-school individualist and, just like Mekas, a poet, Algirdas Šeškus. The narrative based on the juxtaposition of the Lithuanian school of photography with the Fluxus phenomenon has been evolving in the twenty-first century. ${ }^{27}$ This tendency is illustrated by the permanent collection exhibition launched in 2018 at the National Gallery in Vilnius. "Here" contains the Sutkus school and the subsequent anti-Sutkus Lithuanian schools of photography, whereas "there" is represented by the anti-school Fluxus, co-formed by Mekas and Maciunas. A question arises whether we should not take it one step further and completely abandon the here-there dialectic? Dispersion does not have to equal the loss of force and the brand, but can rather mark an openness that is familiar to the contemporary experience, a deschooling in the spirit of Fluxus. The ongoing deschooling of Lithuanian photography is certainly a multifaceted process and requires a shift in the approach towards the subject by Lithuanian researchers themselves, like Agnè Narušytė, mentioned above multiple times. ${ }^{28}$ Deschooling means opening up to the outsiders (Šeškus), emigrant artists (Mekas), women renouncing male dominance (Bubelytè [fig. 2], Michelkevičiūtè), kitsch artists rubbing shoulders with camp (Dichavičius), propagandists wrapped up in Soviet ideology (Giedraitienè, Fišeris, Šiško), outcasts, amateurs, or forgotten artisans (Stanionis). This expansion does not only just concern Soviet-era photography, but also calls for analogous work on "decentralising" the photography of free Lithuania during the interwar period and today, as well as back into the nineteenth century. The asynchronous life of the periods coexisting on Earth enhances the complexity of the general disarray. This disarray ought to be acknowledged and accepted.

26 Photography at MoMA 1960-Now, ed. Quentin Bajac, Lucy Gallun, Roxana Marcoci, Sarah Hermanson Meister, New York: Museum of Modern Art, 2015, p. 172.

27 Lietuvos fotografija / Lithuanian Photography, vols. 1 and 2, sud. Valentinas Klimašauskas, Vilnius: Lietuvos fotomenininkų sajunga, VŠI Lietuvos fotomenininkų sajungos fotografijos fondas, 2018.

28 In an anthology of texts covering the years 1990-2010, Agnè Narušytė is more open and inclusive - and yet, even here, one can find the new post-photographic school. Cf. her Lietuvos fotografija: 1990-2010, Vilnius: Baltos lankos, 2011, pp. 291-328. 


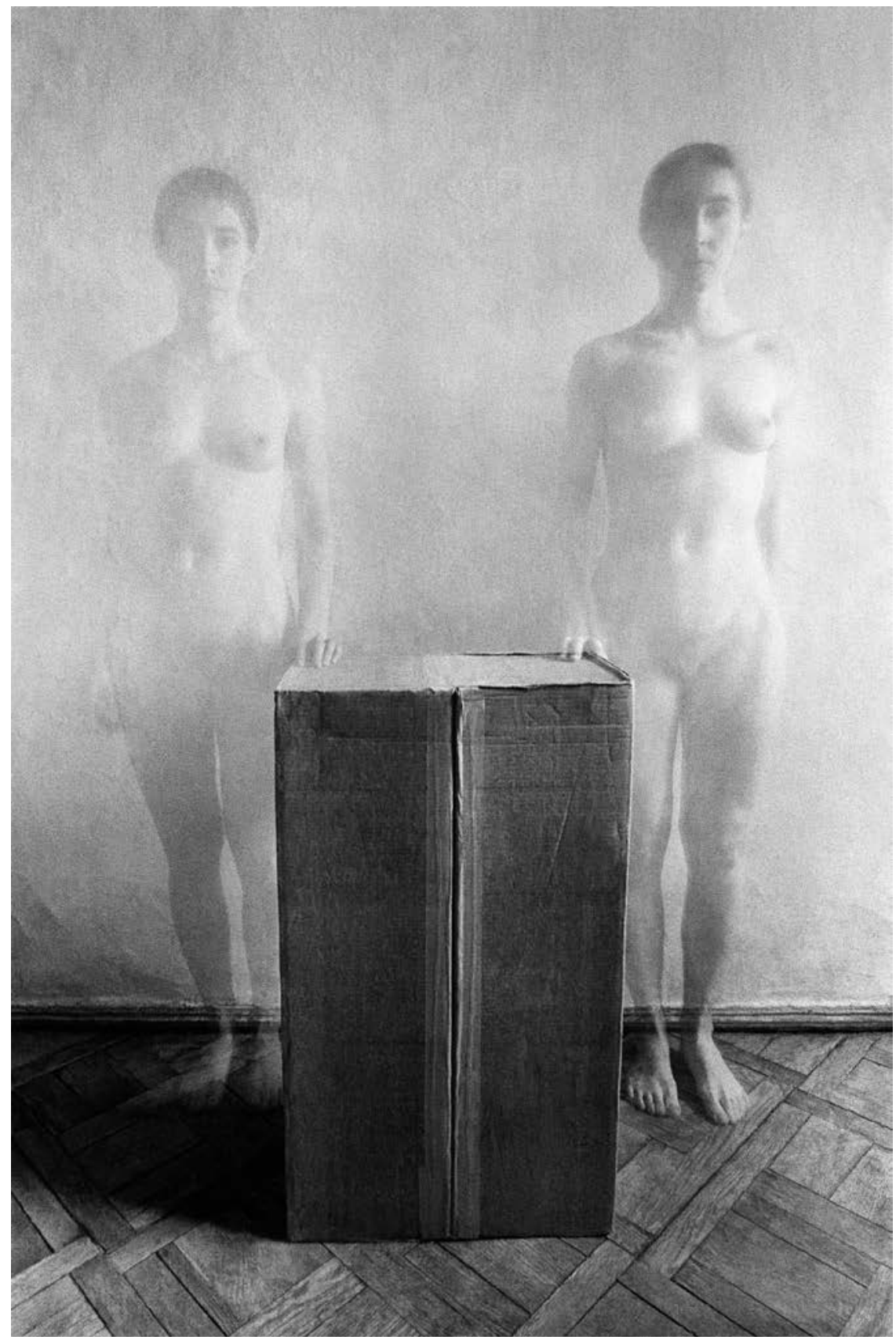

2.

Violeta Bubelytè, Aktas Nr. 29, 1985, $18 \times 27$ cm, sidabro želatininis atspaudas, autorès nuosavybè, LATGA, Vilnius 2021
Violeta Bubelytè, Nude No. 29, 1985, $18 \times 27$ cm, silver gelatine print, LATGA, Vilnius 2021 


\section{A poetic language of expression}

The dichotomies of here and there, East and West, the joy of life and the endless boredom that permeate the discourse are transgressed by artists such as Jonas Mekas, a filmmaker, poet, and photographer. Mekas, who emigrated from Lithuania and became uprooted, who was a New York and neo avant-garde artist to the core, who missed Lithuania and continued to return to Lithuania, counters the straightforward Stalinist constructs and Leninist dialectic with a vision that is poetic, hallucinatory, impressionistic, and beautiful. Historical time begins to bend and New York's skyscrapers, clubs, and parks become interwoven with Lithuanian villages, forests, and fields. Lithuania turns into a field of experimentation with time, subjectivity, and inadequacy of the technical methods of registering images of reality. Lithuania is a utopia, a central European "nowhere", an unmarked territory, where time bends and condenses. Tomas Venclova also noticed that in his writings about Lithuanian literature. ${ }^{29}$ Just like the narrative on literature, the story about Lithuanian photography is incompatible with a simple periodisation, with chapters dedicated to the $19^{\text {th }}$ century, the First World War, the interwar independence of Lithuania, the terror of the Second World War, the Soviet occupation, and the independence regained in 1991. In movies such as Reminiscences of a Journey to Lithuania (1972) and As I Was Moving Ahead Occasionally I Saw Brief Glimpses of Beauty (2000), instead of a straightforward story, Mekas offers a handful of images gathered together into a whole by artistic vision and poetic commentary [fig. 3]. It is a priceless proposal of how one can think and write about Lithuania and Lithuanian photography. Another view of Lithuanian photography could consist of dismissing the Lithuanian school of photography, stripping it of continuity and drawing individual photos, themes, and situations out of its expansive archives. Dispersion and multitude do not signify a lack of identity or weakness. Lithuanian photography, when reduced to a series of iconic images, does not lose any of its essence. What brings together the photographers of the nineteenth and twentieth centuries, the circles of Bułhak and Buračas, Sutkus and Mekas, Budvytis and Kunčius, Bubelytė and Michelkevičiūtè, Miksys and Skudžinskas [fig. 4] is their dedication to beauty and 


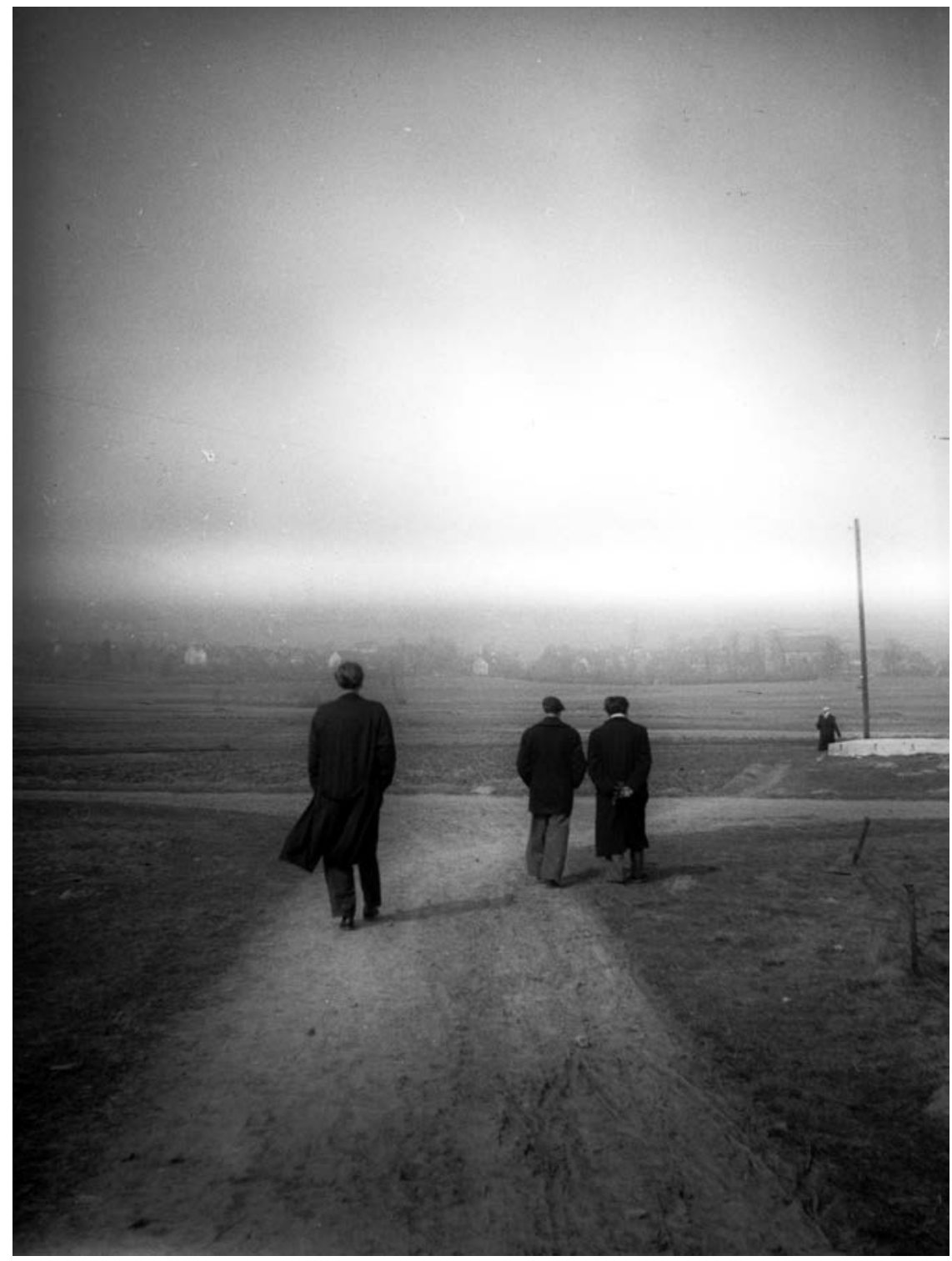

Jonas Mekas, Algirdas Landsbergis, Jonas Mekas ir Leo Adamsas, Kaselis, 1948, Jono Meko paveldètoju nuosavybė
Jonas Mekas, Algirdas Landsbergis, Jonas Mekas and Leo Adams, Kassel, 1948, courtesy: Estate of Jonas Mekas 
poetry. Lithuania is not just a country of photographers, but also of poets. This affinity for lyricism is as exceptional, demanding, and also as hermetic as the Lithuanian language. We witness it in the poetry works of Mekas and Šeškus. When writing about the oeuvre of Marcelijus Martinaitis, the restorer of post-war Lithuanian poetry, Algirdas Greimas notes that Lithuanians are a nation that expresses itself through poetry:

It seems that over the last several decades, Lithuanian culture has been most
expressive in the language of poetry. This is a strange, dangerous, but also very
promising phenomenon. While poets in the West often finance the publication of
their own books, and even then, only manage to sell a few hundred copies at best,
in Lithuania, hundreds of poets write for large audiences who buy and read their
books. This is a very hopeful sign. As long as there is an active appreciation for po-
etry in a nation, human values are not usurped by the hunger for material goods. ${ }^{30}$

Greimas's words could be applied to photography, so utterly important to Lithuanians. While in the West, a photobook or exhibition sees an audience of barely several hundred, in the small country of Lithuania, it is the photographers and fine art photographers that are counted in hundreds, and photography is bought, viewed, and practiced. Nonetheless, as Greimas notes, the national culture assuming a poetic form is at the same time perilous, as, due to its inseparable relationship with the native language, poetry becomes inaccessible for the outside audiences. By the same token, it risks becoming "an isolated, domestic art form, one which cannot be shared with even friends or neighbours [and threatening] to become a Sunday ritual, with no ties to a larger cultural context." ${ }^{31}$ At first sight, photography, which utilises a more universal, visual language, might avoid such a threat. However, photography also demands the knowledge of historical context, cultural codes, and social relations that influenced it. Without such translation it may, just like poetry, become an empty ritual that matters to a narrow community maintaining it, but otherwise remains irrelevant to contemporary reality. Is such translation possible? Is it possible to read

30 Algirdas Julius Greimas, Iš arti iš toli: Literatūra, kultūra, grožis, Vilnius: Vaga, 1995, p. 135, quoted in Brigita Speičytè, "The Art of the Unpoetic Poem: Trends in Post-Soviet Lithuanian Poetry", in: Transitions of Lithuanian Postmodernism: Lithuanian Literature in the Post-Soviet Period, ed. Mindaugas Kvietkauskas, Amsterdam: Editions Rodopi, 2011, pp. 323-348.

31 Algirdas Julius Greimas, quoted in Speičytè, p. 325. 


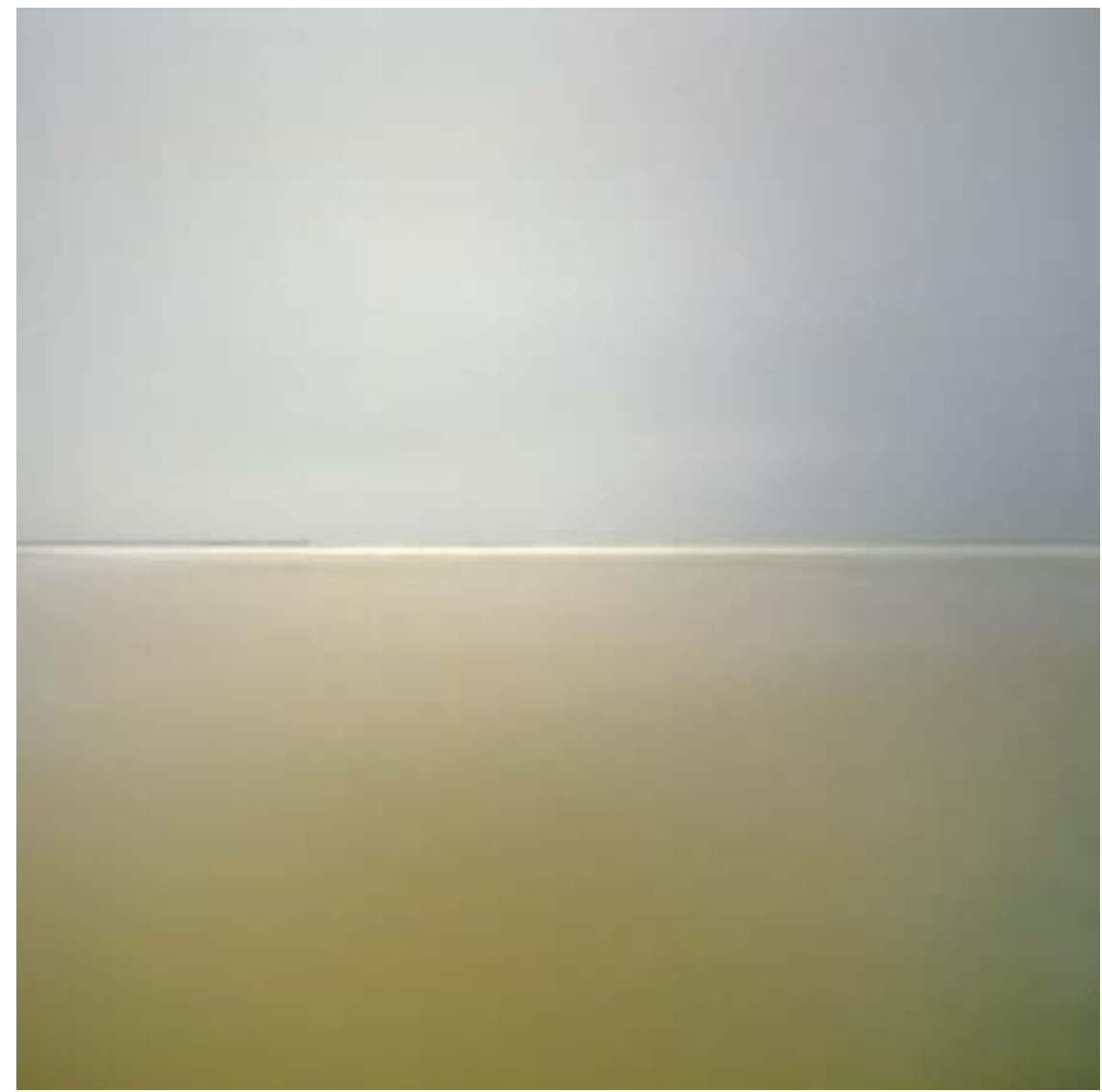

3.

Gytis Skudžinskas, Tyla V,2008-2011, pinhole fotografija / C-Print, ed. 6, autoriaus nuosavybè, LATGA, Vilnius 2021
Gytis Skudžinskas, Silence $V, 2008-2011$, pinhole photography / C-Print, ed. 6, LATGA, Vilnius 2021

photography in a wider public context without slipping into local, provincial, and insignificant disputes? How can this lyricism be preserved? Examples of an effective inclusion of the Czech and Hungarian photography prove that it is not only possible, but also, in fact, profitable for the local scene.

\section{A maze and a photograph}

When it comes to Lithuanian photography, there is no point in searching for precursors and inventors who predate those from Paris or 
London, artists who are subtler than the Viennese or more avant-garde than the Berliners, or street photographers who are more observant than those in New York. Lithuania is a country of stubborn individualists and lyrical aesthetes who have been able to capture exceptional beauty in photographs. Their pictures may not be iconic in the ways that Anglophone, French, or German are, but they are without a doubt original images presenting a new perspective to the historians of the medium. For an attentive viewer, the images constituting the core of Lithuanian photography offer brief, odd, and sudden manifestations of beauty: an unfamiliar beauty, barely revealing itself in certain views, certain colour tones of the world, certain instances. The genius of a Lithuanian photographer consists in capturing those moments and sharing them with others. In Lithuanian photography, those snapshot-like revelations of beauty correspond to moments of deepest sorrow and greatest mourning. They are not photographers' mere impulses or mood shifts, but images referring to the elements of their reality. It is hard to tell what those instances of beauty refer to; we will have better luck guessing where the suffering comes from. It comes as no surprise that at one point in his story, Jonas Mekas states: "I guess I am a romantic."32 Yet another ingredient of Lithuanian photography - if we want to avoid reducing it to a two-dimensional photograph - are the mixed layers of permanence and ephemerality, of that which is to remain and that which will disappear. As Lithuanian photographers demonstrate, everyday reality consists of colliding moments of mortality and immortality. Both are equally important in photography. All of this sounds unusual and is at odds with the photographic discourse focused on technique and superiority. However, Lithuanian photography is a specific maze within which one needs to get lost in order to find what is most valuable. To quote a poem by Tomas Venclova:

Once heavily tilted, the stellar glory floats without direction, The soul coincides with the century, the century is half-erased.

Time imprisons the soul and space is the body's deception, And one can no longer draw the line between photo and maze. ${ }^{33}$ Mekas, 2000.

32 As I Was Moving Ahead Occasionally I Saw Brief Glimpses of Beauty, dir. Jonas

33 Tomas Venclova, Winter Dialogue: Poems, trans. by Diana Senechal, Evanston, IL: Hydra Press, 1997, p. 86. 
When looking at Lithuanian photography, what we need is not a wide angle, but a careful study of individual scenes, situations, and descriptions, and a pause for the trivial observations which can otherwise be easily ignored. The epic, momentum-oriented narrative of the world photography wears out after a while. Meanwhile, the loosely connected pieces, fragments, and photos amounting to a lyrical whole appear to be increasingly engaging. Perhaps it is not the grand moments of historical magnificence, but, as Jonas Mekas notes, those short-lived glimpses of beauty that define our lives.

\section{Submitted $-21 / 10 / 2020$}




\section{Bibliography}

Bajac Quentin, Gallun Lucy, Marcoci Roxana, Hermanson Meister Susan (eds.), Photography at MoMA 1960-Now, New York: Museum of Modern Art, 2015.

Bumblauskas Alfredas, Wielkie Księstwo Litewskie. Wspólna historia, podzielona pamięć, trans. Alicja Malewska, Warszawa: Bellona, 2013.

Benton Maya, Roman Vishniac Rediscovered, Munich: Prestel, 2015.

Donskis Leonidas, Modernity in Crisis: A Dialogue on the Culture of Belonging, New York: Palgrave Macmillan, 2011.

Gravlejs Ivars, Nežinoma Latvijos fotografija, Kaunas: Kaunas Photography Gallery, 2018.

Frizot Michel (ed.), A New History of Photography, Köln: Könemann, 1998.

Greimas Algirdas Julien, Iš arti iš toli: Literatūra, kultūra, grožis, Vilnius: Vaga, 1995.

Gudaitè Jūratè (ed.), Jan Buthak. Vilnius, vols. 1-3, Vilnius: Lietuvos nacionalinis muziejus, 2011, 2012, 2013.

Gudaitè Jūratė (ed.), Juozapas Čechavičius 1818-1888. Fotografijos / Photographs, Vilnius: Lietuvos nacionalinis muziejus, 2016.

Ivaškevičius Marius, Historia z chmury, Wołowiec: Wydawnictwo Czarne, 2001.

Junevičiaus Dainius, Abdonas Korzonas - pirmasis Vilniaus vaizdu fotografas, Vilnius: Vilniaus dailès akademijos leidykla, 2018.

Klimašauskas Valentinas (ed.), Lietuvos fotografija / Lithuanian Photography, vols. 1 and 2, Vilnius: Lietuvos fotomenininkų sajunga, VŠI Lietuvos fotomenininkų sajungos fotografijos fondas, 2018.

Kvietkauskas Mindaugas (ed.), Transitions of Lithuanian Postmodernism: Lithuanian Literature in the Post-Soviet Period, Amsterdam: Editions Rodopi, 2011.

Kvietkauskas Mindaugas (ed.), The Ghetto Lane in Wilna. Hommage à Moi Ver, Vilnius: The Institute of Lithuanian Literature and Folklore, 2019.

Laukaitiené Vaiva, Żak, Natalia (ed.), Mikalojus Konstantinas Čiurlonis. Litewska opowieść / Lithuanian Tale, Kraków:

Międzynarodowe Centrum Kultury, 2015.

Macek Vaclav (ed.), The History of European Photography 1900-1938, vol. 1, Bratislava: Central European House of Photography, 2010.

Macek Vaclav (ed.), The History of European Photography 1939-1969, vol. 2, Bratislava: Central European House of Photography, 2014

Macek Vaclav (ed.), The History of European Photography 1970-2000, vol. 3, Bratislava: Central European House of Photography, 2016.

Madon-Mitzner Katarzyna (ed.), Stanistaw Kazimierz Kossakowski. Kocham fotografie. For the Love of Photography. Myliu fotografija, Warszawa: Dom Spotkań z Historią, 2019.

Matulytė Margarita, Nihil obstat. Lietuvos fotografija sovietmečiu, Vilnius: Vilniaus dailès akademijos leidykla, 2011.

Matulytė Margarita, Luckienè-Aldag Tatjana (eds.), Works, Kaunas: Lietuvos dailès muziejus, 2014.

Matulytė Margarita, Narušytė Agnè, Camera Obscura. Lietuvos fotografijos istorija 1839-1945, Vilnius: Vilniaus dailès akademijos leidykla, 2016.

Michelkevičius Vytautas, Michelkevičè Lina, Narušytė Agnė, eds., Mapping Lithuanian Photography. Histories and Archives, Vilnius: Mene, 2007.

Michelkevičius Vytautas, The Lithuanian SSR Society of Art Photography (1969-1989). An Image Production Network, Vilnius: Vilnius Academy of Arts Press, 2011.

Miksys Andrew, Tulips, Vilnius: ARÖK Books, 2016.

Mulevičiūtė Jolita, “Vaitkuškis”. Grafas Stanislovas Kazimieras Kosakovskis (1837-1905) ir XIX amžiaus mègèju fotografija, Vilnius: Lietuvos kultūros tyrimu institutas, 2015.

Narušytė Agnè, The Aesthetics of Boredom. Lithuanian Photography 1980-1990, Vilnius: Vilniaus dailès akademija, 2010. 
Narušytė Agnè, Lietuvos fotografija: 19902010, Vilnius: Baltos lankos, 2011.

Parr Martin, Vikšraitis Rimaldas, The Real World, Kaunas: Kaunas Photography Gallery, 2010.

Witkovsky Matthew S., Foto: Modernity in Central Europe 1918-1945, Washington: National Gallery of Art, 2007.

Venclova Tomas, Ksztalty nadziei, Warszawa: Niezależna Oficyna Wydawnicza, 1995.

Venclova Tomas, Winter Dialogue: Poems, Evanston, IL: Hydra Press, 1997.

Vytautas Stanionis. Nuotraukos dokumentams / Photographs for Documents, Kaunas: Kaunas photography gallery, 2013.

Советское фото, 9, 1969. 
Santrauka

\title{
Trumpi grožio blyksniai. Apmąstant Lietuvos fotografijos istoriją
}

\author{
Adam Mazur
}

Reikšminiai žodžiai: Lietuvos fotografija, Lietuvos menas, Lietuvos istorija, dokumentinè fotografija, fotografijos menas, Balys Buračas, Janas Bułhakas, Antanas Sutkus, Jonas Mekas.

Lietuvos fotografija yra viena geriausiai aprašytų, tačiau nė vienoje išsamioje pasaulio fotografijos istorijos studijoje nėra autorių ar fotografų iš Lietuvos. Kodèl vis dar susiduriame su „nežinomos Lietuvos fotografijos" situacija? Šis fundamentalus klausimas skatina kelti tolesnius: ar galime bent ịsivaizduoti kitokia Lietuvos fotografijos istoriją? Straipsnyje siūloma iš naujo ịsivaizduoti Lietuvos fotografijos naratyvą. Pirmiausia, imamasi Lietuvos fotografijos nacionalinio išskirtinumo problemos, remiantis Greimo konceptualizuota sąvoku „,̌̌ia“ ir „ten“ opozicija, aiškinamasi, kas iš tikrujų laikoma Lietuvos fotografija. Straipsnyje propaguojamas istoriografinio diskurso pratęsimas ir įtraukumas peržengtų netgi už Didžiosios Lietuvos Kunigaikštystės ribas, atsiveriant kitoms fotografijos tradicijoms: vokiečių, rusų, lenkų, žydų ar amerikiečių. Antra, straipsnio autorius ragina pradèti „fotografijos išmokyklinimo“ procesą, sustiprinant ịkvepianti Lietuvos fotografijos heterogeniškumą ir priešinantis sovietmečiu sukurtam vadinamosios Lietuvos fotografijos mokyklos mitui. Trečia, siūloma ieškoti sąsajų su pačios medijos takia tapatybe, kurią išnaudojo neapibrèžta FLUXUS grupè, susibūrusi aplink emigrantus iš Lietuvos Jurgị Mačiūną ir Joną Meką. Galiausiai, kas paprastai, regis, lieka nepastebèta Lietuvos fotografiją supančiame diskurse, tai jos poetinè išraiškos kalba. Galbūt tai ir nèra didingi istorinės reikšmės momentai, bet, kaip pastebi Jonas Mekas, tie „trumpi grožio blyksniai“ apibūdina mūsų gyvenimus.

$99-2020$

Acta Academiae Artium Vilnensis 